\title{
THERMAL ACTIONS ON THE MATERIALS DURING DECK AND PAVEMENT CONSTRUCTION
}

\section{B. CHMIELEWSKA ${ }^{1}$, A. GARBACZ ${ }^{2}$, G. ADAMCZEWSKI ${ }^{3}$, B.RYMSZA ${ }^{4}$}

The article presents the results of the research on thermal actions on the materials occurring in the cross section along the depth of the bridge deck and bituminous pavement during its construction. The impulse to curried out the research was the need to explain the causes of the blistering of bituminous waterproofing membranes and asphalt pavements often observed on the bridge decks. The paper presents the examples of such failures and the analyses of possible mechanisms of the phenomenon. Research indicates a significant influence of all technological processes on the temperature of materials in the cross section as well as daily temperature changes. The probability of initiation of reactions between concrete components with gaseous products has been confirmed in such conditions. The susceptibility of bituminous materials to gas emission and blistering is the subject of a separate study. The research was part of a research project carried out under the contract INNOTECHK3/IN3/50/229332 /NCBR /14 [13].

Keywords: blistering, waterproofing membrane, bridge deck, asphalt pavement, thermal action

\footnotetext{
${ }^{1}$ PhD., Warsaw University of Technology, Faculty of Civil Engineering, ul. L. Kaczyńskiego 16, 00-637 Warsaw, Poland, e-mail: b.chmielewska@il.pe.edu.pl

${ }^{2}$ Prof., DSc., PhD., Eng., Warsaw University of Technology, Faculty of Civil Engineering, ul. L. Kaczyńskiego 16, 00-637 Warsaw, Poland, e-mail: a.garbacz@il.pe.edu.pl

${ }^{3}$ PhD., Eng., Warsaw University of Technology, Faculty of Civil Engineering, ul. L. Kaczyńskiego 16, 00-637 Warsaw, Poland, e-mail: g.adamczewski@il.pe.edu.pl

${ }^{4}$ Prof., DSc., PhD., Eng., Road and Bridge Research Institute, 1, Instytutowa str.,03-302 Warsaw, Poland, e-mail:brymsza@ibdim.edu.pl
} 


\section{PROBLEM DESCRIPTION}

The problem concerns blisters containing gas under pressure, which arise on waterproofing bituminous membranes on concrete decks. This phenomenon is often encountered during bridges and viaduct construction, what is well documented by Road and Bridge Research Institute in Poland [1] and in publications $[2,3,16]$. Blisters form on the membranes (Fig. 1a) from a few to dozen and few days after application or even after application of asphalt pavement (Fig. 1b). Diameter of blisters varied from a few centimetres even to $1 \mathrm{~m}$. It increases the cost of the investment as well as delay in commissioning. Not often a composition of gases in blister is subjected to chemical analysis. However, at least in a few cases quantitative chromatography analysis detected a huge amount of hydrogen in samples of gases taken from blisters at construction site.

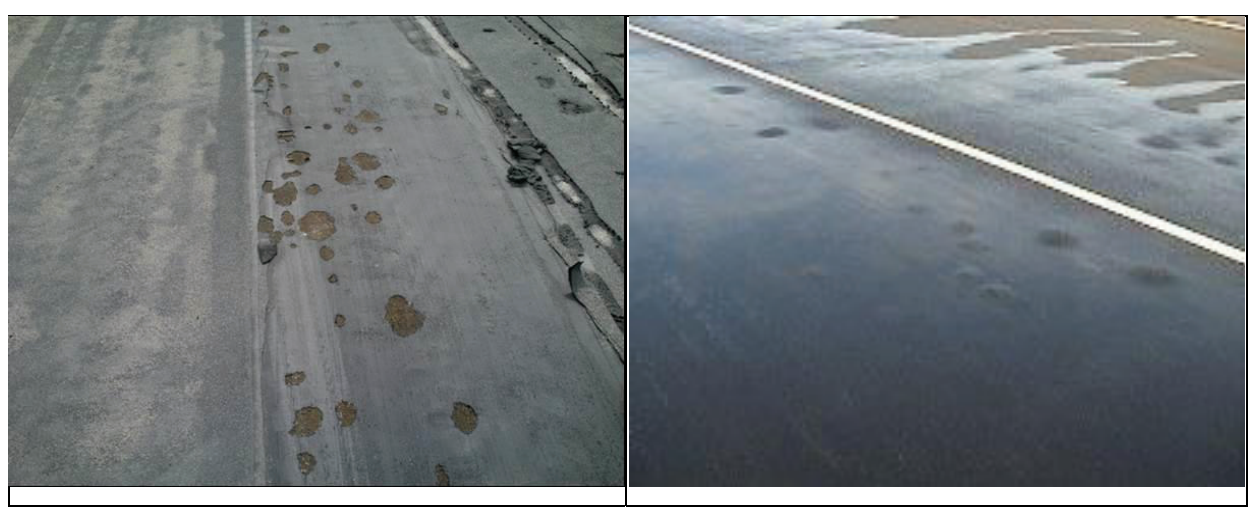

Fig. 1 Blisters containing gas on a) the waterproofing membrane b) the asphalt pavement

In one case (viaduct in Katowice, over Bracka str.; year 2003) the blisters appeared on the surface of about $3000 \mathrm{~m}^{2}$ of waterproofing membrane during two weeks after insulation was placed. Some of them reached diameter about $1 \mathrm{~m}$. The analysis curried on by two independent laboratories show similar gas composition [2,3], what more gas burned with colourless flame characteristic for hydrogen:

$1^{\text {st }}$ lab.: $\mathrm{H}_{2}(42 \%), \mathrm{N}_{2}(57 \%) \mathrm{O}_{2}(0,6 \%), \mathrm{C}_{1}-\mathrm{C}_{4}$ hydrocarbons $(0.1 \%)$; the following substances as: $\mathrm{CO}, \mathrm{CO}_{2}$, benzene, toluene, xylene were not found, 2nd lab.: $\mathrm{H}_{2}(34 \%), \mathrm{N}_{2}(62 \%), \mathrm{CO}(0,2 \%)$, C1-C5 hydrocarbons (3,5\%); $\mathrm{CO}_{2}$ - not found. In the second case (A4 highway, Rzeszów; year 2011) the high concentration of hydrogen in gasses was also discovered in gas samples taken from a construction site. In both cases a repair of blisters 
by placing patches or totally new waterproofing system resulted in the new blisters appearance with decreasing intensity. In both cases a styrene butadiene styrene (SBS) modified bituminous sheet materials with polyester reinforcement were used.

There are several mechanisms of blistering of coatings discussed in literature. Phenomenon is well known also for industrial floors and other type of protective coatings on concrete as well as insulating layers on roofs. Osmotic, diffusive, thermal and chemical mechanisms are considered when analysing the phenomenon $[3,4,5,6]$. One of the most important information needed to undergo such analysis is to determine what substances are in the blister, what gives the effect of volume expansion. Depending on the mechanism the blisters can be wet or dry, may contain gases, solutions, gels or precipitates.

\section{POTENTIAL MECHANISM OF HYDROGEN PRESENCE IN BLISTERS}

In previous work a few hypothesis were discussed and investigated to explain the reason of hydrogen presence in the blisters $[2,3,17]$. Two mechanisms are most likely:

$1^{\text {st }}$ - thermal decomposition of organic components in the waterproofing system,

$2^{\text {nd }}$ - chemical reactions between inorganic compounds in the concrete base.

Mechanism no. 1 is analysed on the base of a "hot process" hypothesis and mechanism no. 2 on a "cold process" hypothesis. The first one assumes degradation of the waterproofing system induced by heating or overheating of the sheet membrane and the primer during installation works. Sheet membranes consist mainly of bitumen modified with styrene-butadiene-styrene copolymer and a polyester reinforcing net. Bituminous primer is a solution of bitumen in a mixture of organic solvents [18].

The second mechanism takes into account a significant thermal action on a concrete slab due to an ambient temperature or due to the placing of the hot subsequent layers (membrane, mastic asphalt, stone mastic asphalt) during all stages of pavement construction. "Cold process" assumes, that chemical reaction proceeds in the temperature reached by concrete deck; expected as significantly lower than of bituminous materials. The reaction of free metal as aluminium ( $\mathrm{Al}$ ) or metalloid as silicon ( $\mathrm{Si}$ ) with the cement paste is most likely in this case. Aluminium is used as an additive to the expansive grout for prestressing tendons. It was also indicated that the aggregate surface can be contaminated by $\mathrm{Al}$ due to the abrasion of metal containers. Silicon can comes from silica fume, a by-product of ferrosilicon production which is widely used in concrete technology $[7,8,9,10,11]$. 
Thermodynamic analysis of potential reactions between silicon and water or calcium hydroxide [3] indicates exothermic effect. Their equilibrium constants, are proportional to equilibrium pressures of hydrogen and are diminished functions of temperature. The equilibrium pressures of hydrogen, in the analysed range of temperature $\left(0-100^{\circ} \mathrm{C}\right)$ are incomparably higher $\left(10^{33}-10^{20}\right.$ bars $)$ than atmospheric pressure $[2,12]$. It means that all considered reactions are spontaneous. Under atmospheric pressure the reactions can proceed to completion. Another factor, which decides if the reaction undergo is a kinetic of the reaction. Investigations indicated, that e.g rate of the reaction of $\mathrm{Si}$ in alkaline water solution significantly increases, when temperature reaches $35^{\circ} \mathrm{C}$ and once the temperature gets into $50-60{ }^{\circ} \mathrm{C}$ range the rate of gas evolution is high [10].

\section{GOAL AND SCOPE OF INVESTIGATION}

In order to carry out a discussion whether the mentioned above bituminous materials or concrete deck are a potential source of the gases (especially hydrogen) in blisters it was necessary to measure the real temperature of the materials on a site, during road construction. Knowledge how this temperature influence the jointed materials brings possibility to get answers about the most likely causes of blistering of bituminous insulation.

A concrete slab of the bridge deck being a part of dual carriageway (A2, near Lodz), was chosen and tested (Fig. 2). It included in one direction, three traffic lanes, an emergency lane and a pavement with total width $17 \mathrm{~m}$. Bridge deck $(\mathrm{g}=80 \mathrm{~cm}, \mathrm{C} 35 / 45)$, abutment and pavement (C30/37) was made of reinforced concrete.

The intention of the authors was to take measurements during the hottest days of summer $\left(\mathrm{T}>30^{\circ} \mathrm{C}\right)$. Unexpected delay in construction resulted in shifting the main works to the beginning of autumn, when temperature decreases to $10^{\circ} \mathrm{C}$, and in the night even more. The research was carried out over several months in accordance with the construction schedule (Tab.1). 


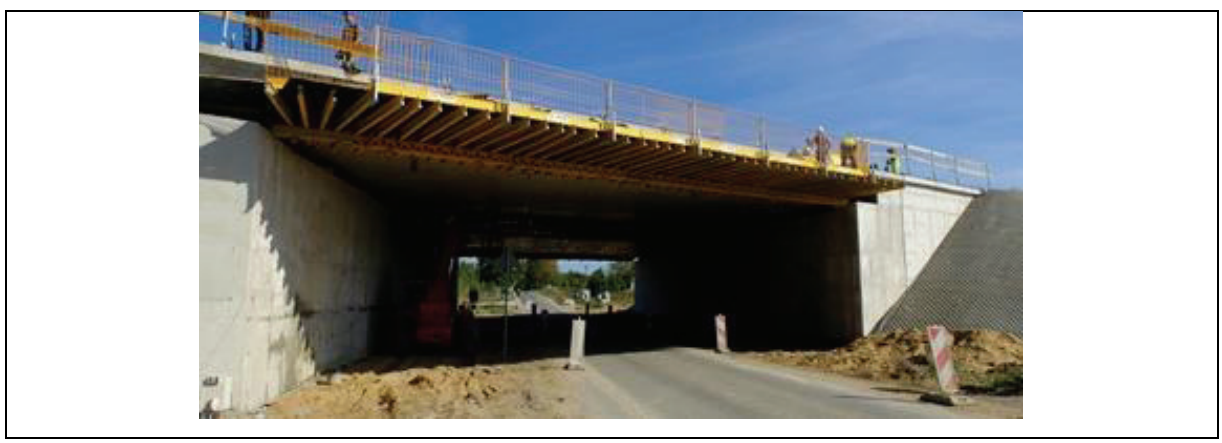

Fig.2 The view of the bridge deck at the A2 carriageway under construction.

Table 1 Schedule of the bridge deck construction

\begin{tabular}{|c|c|}
\hline Date & Selected stages of construction \\
\hline 25.06 .2015 & The slab of the deck casting \\
\hline 17.09 .2015 & Placement of bituminous membrane on the pavement along the road (Fig.3) \\
\hline 05.10 .2015 & Placement of bituminous membrane on the traffic and emergency lanes \\
\hline 07.10 .2015 & Placement of mastic asphalt (MA) \\
\hline 19.10 .2015 & Placement of stone mastic asphalt (SMA) \\
\hline
\end{tabular}

The research plan focused on the measurements of temperature of the materials built into the deck (concrete - waterproofing insulation - mastic asphalt - stone mastic asphalt) and temperature in the formed materials joints. Measurements included (Fig 3) the following materials:

- the concrete in the concrete slab cross section along the depth:

- the upper part; about $10 \mathrm{~cm}$ below the surface of the slab; top points no.1T and $2 \mathrm{~T}$,

- the middle part; a half depth of the slab; centre points no. $1 \mathrm{C}$ and $2 \mathrm{C}$,

- the lower part; about $5 \mathrm{~cm}$ above bottom of the slab; bottom points no.1B and 2B,

- a surface layer of the slab; $0,5 \mathrm{~cm}$ below the surface (10 points from no. 0.1 to 3.3 ),

- bituminous waterproofing membrane; sheet based material with polyester reinforcement; from the upper side protected by sand layer and from the bottom side a PET foil,

- mastic asphalt (MA), stone mastic asphalt (SMA).

Moreover shade air temperature $\left(\mathrm{T}_{\text {out }}\right)$ and humidity were constantly monitoring. 


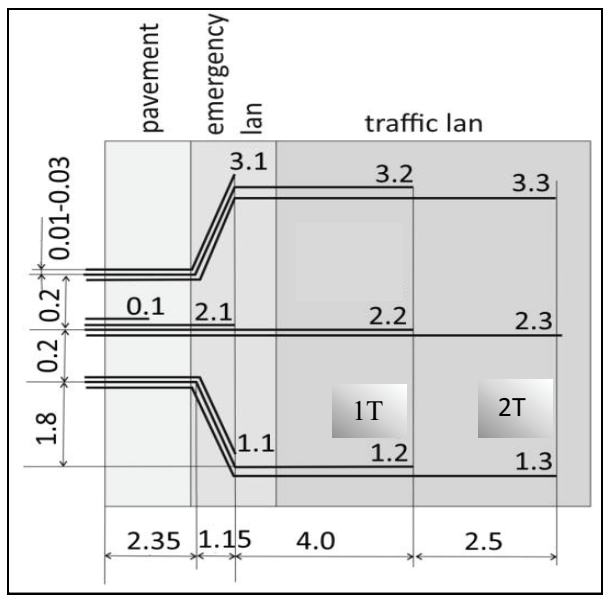

Fig. 3 The geometry of the sensors fixed on the deck. From 0.1 to 3.3 the TKP type. 1T and 2T - the T type; six were fixed across the deck cross section: 1 and $2 \mathrm{~T}$-top and beneath them $\mathrm{C}$ - in the centre, $\mathrm{B}$ - in the bottom. All dimensions in meters

\section{MeASURing APPARATUS}

Temperature measurements of the bridge deck across its depth, during concrete casting, hardening and placement of the asphalt pavement layers were carried out using system ConReg 700 with six thermocouples type T (Fig.3, Fig.4). Frequency of sampling varied from 1 per 1 min to 1 per $1 \mathrm{~h}$. To measure the high temperature of bituminous materials the registration system was used, which consisted of ten thermoelectric sensors type TKP (range $-40 \div+1100^{\circ} \mathrm{C}, \varphi=1,5 \mathrm{~mm}$ ) connected to the electronic data acquisition system. Frequency of sampling varied from 1 per $1 \mathrm{~s}$ to 1 per $1 \mathrm{~h}$. Outer temperature and humidity were registered by Apar AR235. Systems were powered by two VRLA battery (gel cell) and UPS. However, a part of data was lost when the system was powered by electricity supplied for construction site, which was unstable. Moreover a thermal imaging camera Fluke Ti400 with wide-angle lens was used to assess surface temperature changes (range: $-20 \div$ $+1200^{\circ} \mathrm{C}$ ) over time. 


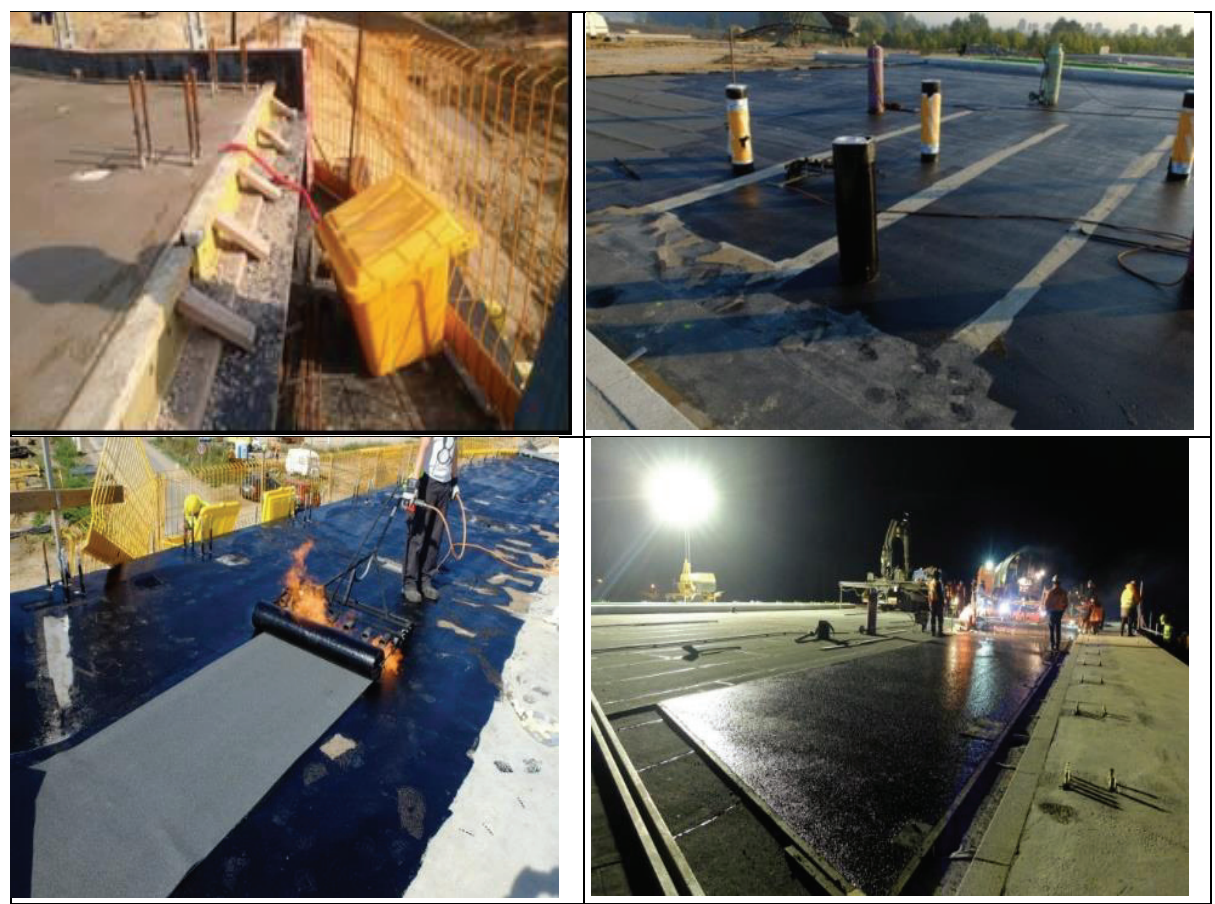

Fig.4 The pavement construction. Sensors fixed inside the deck and put into the box, which contained the data acquisition devices. Visible location of the sensors on the surface; thegrey stripes on a primer black background.

\section{THERMAL ACTIONS ON THE MATERIALS DURING CONSTRUCTION}

\subsection{CONCRETE SLAB CASTING}

Concrete works took place on June 25th (12:20). ConReg registrated the temperature along the depth of the concrete slab during the concrete setting (Fig.5), and then for three months (Fig.6); The highest temperature $\left(65^{\circ} \mathrm{C}\right)$ was observed in the midle part of the slab $(1 \mathrm{Center})$ and the lowest $\left(55^{\circ} \mathrm{C}\right)$ on the top (1Top) during first two days after concrete plaicing. Than temperature decreased and daily changes (cycles) were observed (Fig.6), when $\mathrm{T}_{\text {out }}=+5 \div+41^{\circ} \mathrm{C}$, when highest temperature in central Poland is $+43{ }^{\circ} \mathrm{C}$ [14]. The mostly hitted part of the concrete slab was its top part with $\mathrm{T}_{\max }=39,6{ }^{\circ} \mathrm{C}$ in July and August and $35,2^{\circ} \mathrm{C}$ in September; the lowest temerature reached respectively $14,9,14,9$ and $9,2{ }^{\circ} \mathrm{C}$ in that time. Maximum daily changes of the temperatur (Tab.2) in the cros section of the deck along the depth $\left(\Delta \mathrm{T}=10,8{ }^{\circ} \mathrm{C}\right)$ ocured between the top of the plate $(1 \mathrm{~T}, 2 \mathrm{~T})$ and its bottom $(1 \mathrm{~B}$, 
2B). Taking into account the surfacing factor $\mathrm{k}_{\text {sur }}=1,5$ for such structure it can be expected that under black insulation membane the top of the slab can reach the temperature of $60{ }^{\circ} \mathrm{C}$ PN-EN 1991-1-5 $[14,15]$.

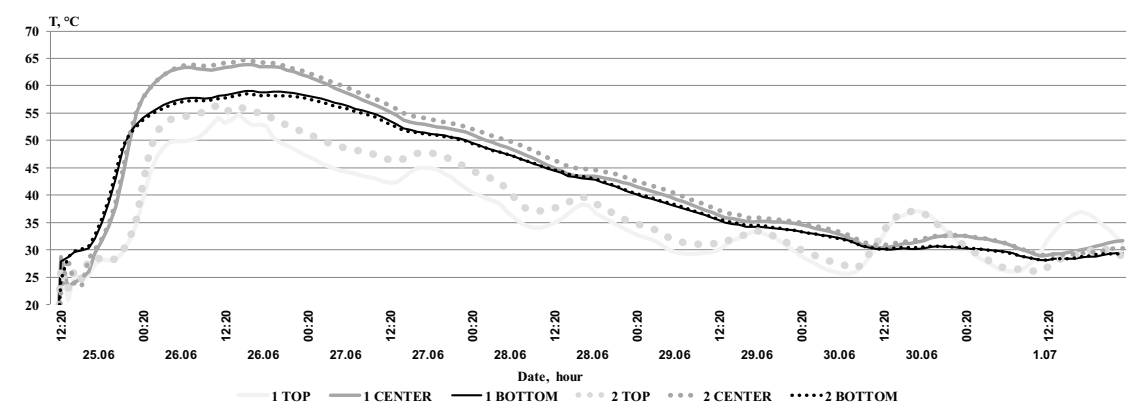

Fig 5 Temperature of concrete mesured along the depth of the bridge deck during casting and seting between 25.06 and 1.07 2015. Differences between top, center and bottom of the slab are seen.

Table 2 The values of linear temperature difference $\left(\Delta \mathrm{T}_{\mathrm{M}}\right)$, along the depth of the deck cross section.

\begin{tabular}{|c|c|c|c|c|}
\hline $\begin{array}{c}\text { Top on the depth } \\
\text { of about } 10 \mathrm{~cm}\end{array}$ & $\begin{array}{c}\text { Top warmer than } \\
\text { bottom } \\
\mathrm{T}_{\mathrm{TOP}}-\mathrm{T}_{\mathrm{BOTTOM}}\end{array}$ & $\begin{array}{c}\text { Top colder than } \\
\text { bottom } \\
\mathrm{T}_{\text {BOTTOM }}-\mathrm{T}_{\mathrm{TOP}}\end{array}$ & $\begin{array}{c}\text { Center warmer than } \\
\text { bottom } \\
\mathrm{T}_{\text {CENTER }}-\mathrm{T}_{\mathrm{BOTTOM}}\end{array}$ & $\begin{array}{c}\text { Center colder than } \\
\text { bottom } \\
\mathrm{T}_{\text {BOTTOM }}-\mathrm{T}_{\text {CENTER }}\end{array}$ \\
\hline Month & \multicolumn{3}{|c|}{$\Delta \mathrm{T}_{\mathrm{M}},{ }^{\circ} \mathrm{C}$} & 2,6 \\
\hline July & 10,8 & 5,3 & 2,8 & 1,0 \\
\hline August & 9,9 & 3,1 & 3,7 & 1,5 \\
\hline September & 6,5 & 3,7 & 3,6 & \\
\hline
\end{tabular}



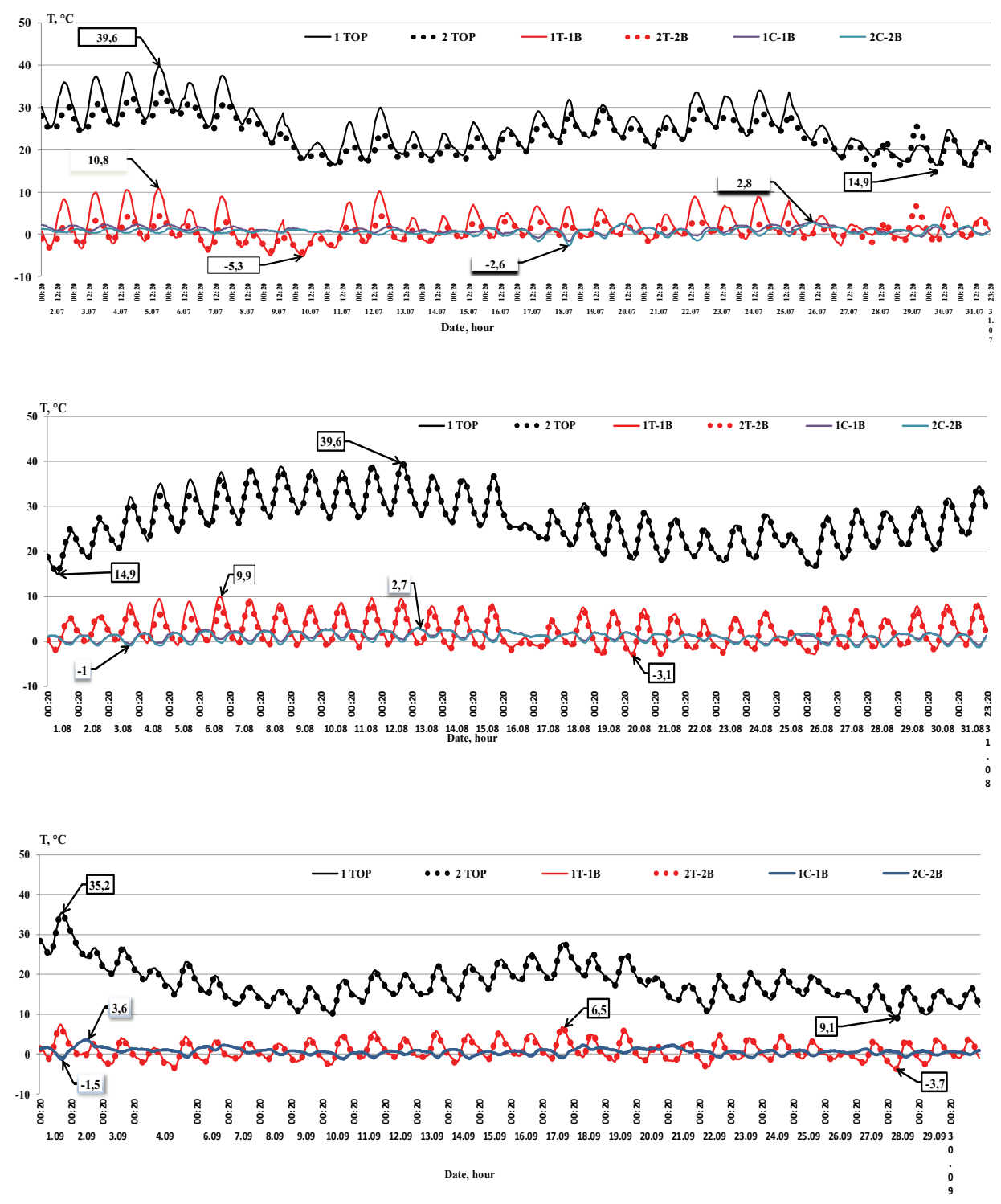

Fig. 6 Changes of the temperature along the depth of the deck cros section mesured in two points 1TOP and 2 TOP from 02.07 to 31.09 2015. Differences in temperature between the top and the bottom of the deck (1T$1 \mathrm{~B}, 2 \mathrm{~T}-2 \mathrm{~B})$ and between center and bottom part (1C-1B, 2C-2B) are also presented. Numbers indicate the highest and the lowest values during each month. 


\subsection{Placement OF THE BITUMinOUS WATERPROOFING MEMBRANE}

The works included: the deck surface preparation, application of a bituminous primer, heating the sheet membrane with a blowtorch, sealing the overlap seams with a hand roll.

Measurements during placement of the membrane indicated, that:

-the highest momentary temperature of the sheet surface, detected just after contact with the torch was in the range $750-823{ }^{\circ} \mathrm{C}$ (Fig. 7a).

-the temperature of bituminous binder, which was flowing down from the roll, without contact with the flame was about $500 \div 600^{\circ} \mathrm{C}$ (Fig. $7 \mathrm{c}$ ),

-when the binder reached the slab its temperature decreased to about $270 \div 312{ }^{\circ} \mathrm{C}$ (Fig. $7 \mathrm{c}$, Fig. $7 \mathrm{~b}$ ), then was still kept in the range $160 \div 340^{\circ} \mathrm{C}$, over a dozen seconds, despite a quick cooling of the surface below $100^{\circ} \mathrm{C}$ (Fig. 8 a, b). $50{ }^{\circ} \mathrm{C}$ was reached on the surface in $10 \mathrm{~min}$ and $\mathrm{T}>40{ }^{\circ} \mathrm{C}$ were kept more than $35 \mathrm{~min}$. (Fig $8 \mathrm{a}, \mathrm{b}$ ). However it was strongly depended on the wind direction (Fig 8 c, d).

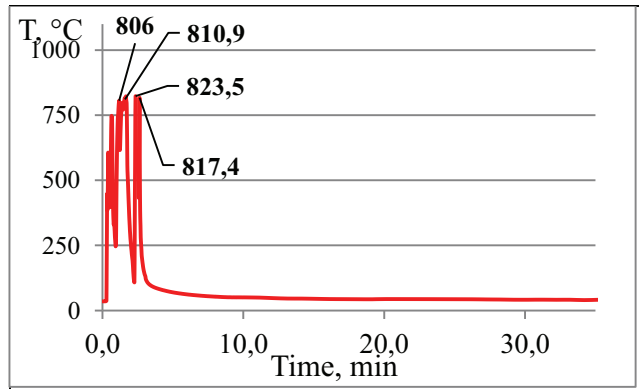

a)

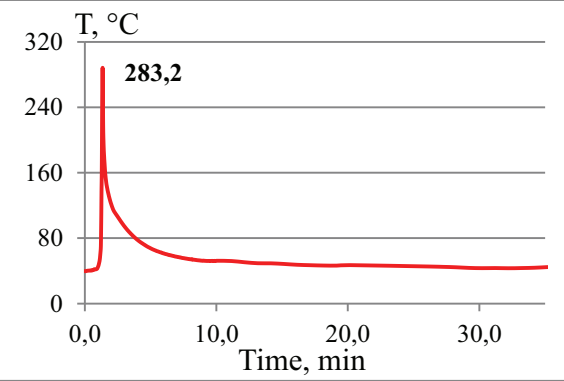

b)

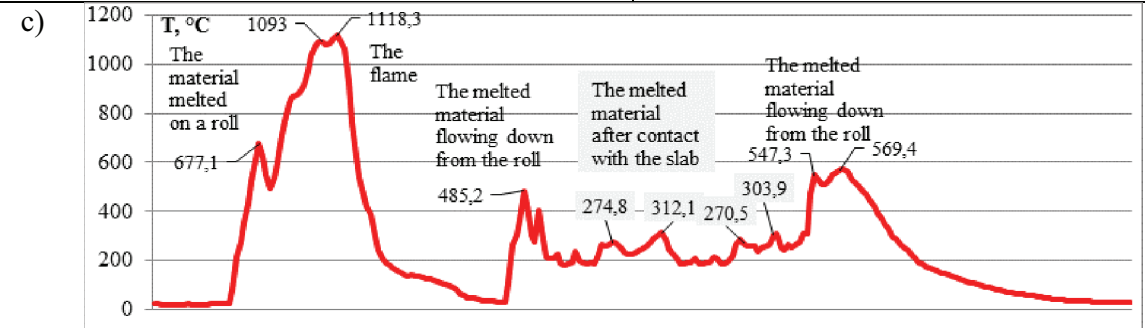

Fig. 7 Temperature of bituminous binder during placement of waterproofing membrane measured a) after flame action on the roll (picks) c) when it flowing down from the roll to the concrete - the sensor placed manually - measurements in seconds (picks), b) when it reached the concrete and was covered by the sheet. 


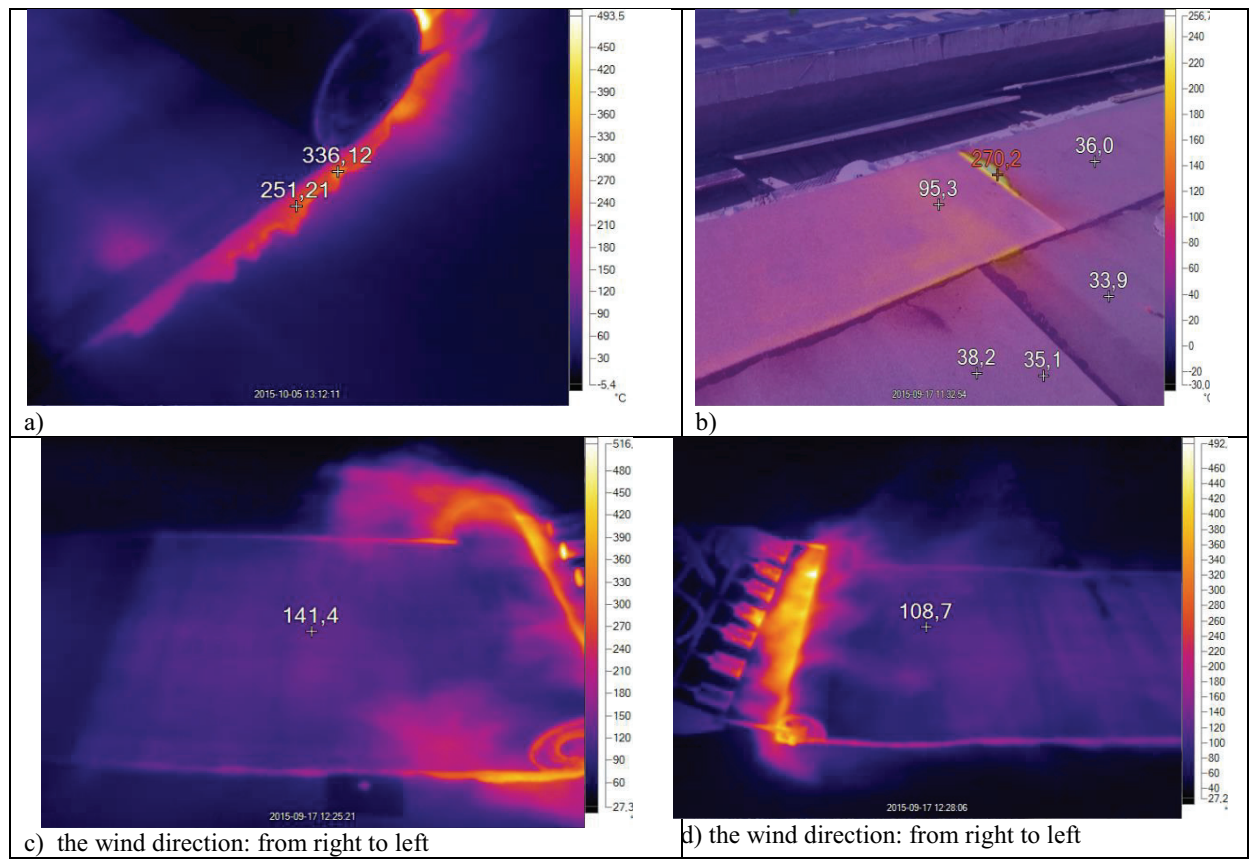

Fig. 8 The insulation membrane placement (17.09'15); IR camera indicates the temperature: a), b) of melted bitumen, which flows out from under the sheet as well as at its surface $\left(\mathrm{T}_{\text {out }}=25,3 \mathrm{C}\right)$; c), d) when sheet is unrolled $c)$ against the wind or $d)$ with the wind direction $\left(T_{\text {out }}=29,7 \mathrm{C}\right)$.

\subsection{Placement OF THE MASTIC ASPHALT AND THE STONE MASTIC ASPHALT}

Mastic asphalt having $\mathrm{T} \sim 240{ }^{\circ} \mathrm{C}$ and placed when the $\mathrm{T}_{\text {out }} \leq 5{ }^{\circ} \mathrm{C}$ reached $\mathrm{T}=22{ }^{\circ} \mathrm{C}$ after $2 \mathrm{~h}$ (Fig. 9 $\mathrm{a}, \mathrm{b}$ ). The SMA layer was laid on a MA, when during a few hours of construction work the outer temperature changed from $12{ }^{\circ} \mathrm{C}$ to $6{ }^{\circ} \mathrm{C}$ and then to $20^{\circ} \mathrm{C}$. The SMA having $\mathrm{T}=170-180{ }^{\circ} \mathrm{C}$ (Fig. 9 c, d) after application cooled to $150-170{ }^{\circ} \mathrm{C}$. Compaction of the mixture done, when the surface temperature was around $50-100{ }^{\circ} \mathrm{C}$. Despite such low outer temperature the process significantly influenced the temperature of concrete slab in the top layer. 


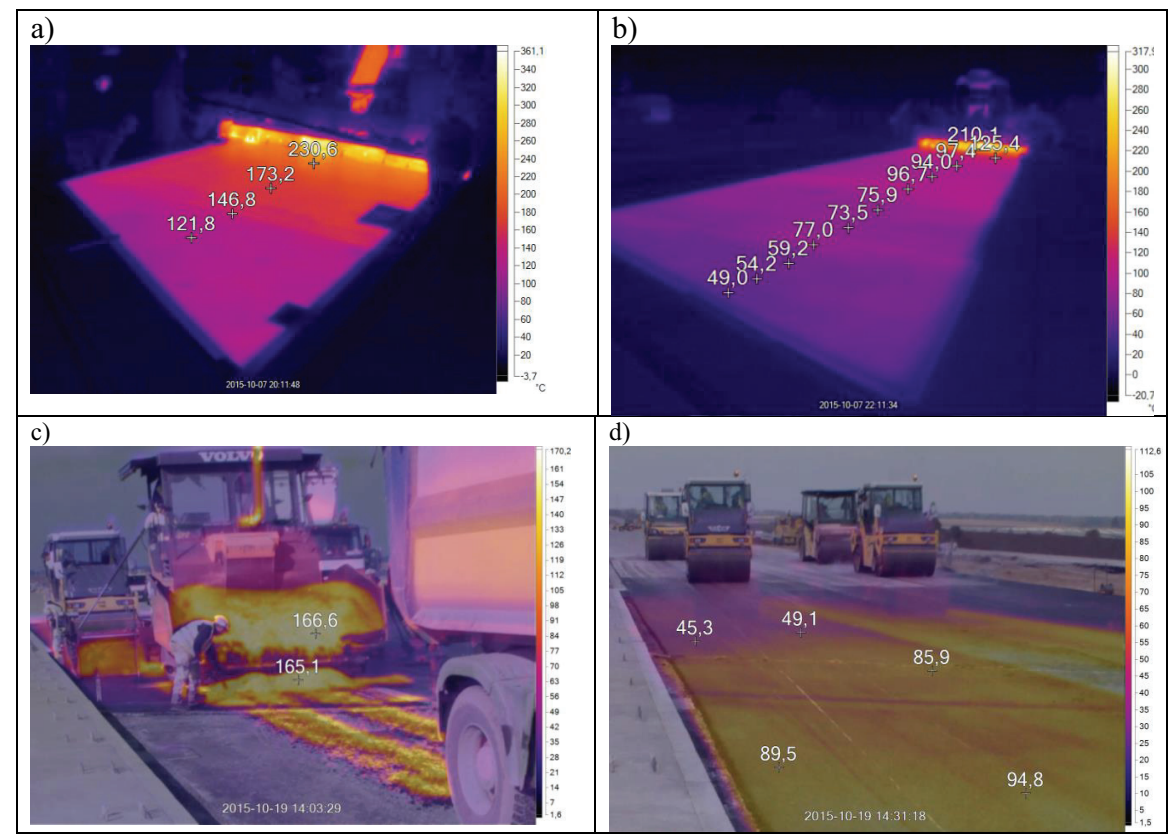

Fig. 9 Placement of a), b) mastic asphalt and c), d) SMA; temperature detected using IR camera

\subsection{TEMPERATURE OF CONCRETE DECK}

It was established (Fig.10, Tab. 2, Tab. 3) that placing of the subsequent layers during the road construction influences the temperature of the slab:

a. waterproofing membrane (Tab.3); the concrete slab having $\mathrm{T}=13-15^{\circ} \mathrm{C}$ (points $1 \mathrm{~T}$ and $2 \mathrm{~T}$ ) in early morning (8:20) was heated to $70 \div 140^{\circ} \mathrm{C}$ on its surface - points from 1.1 to 3.3 , at the depth of $0,5 \mathrm{~cm}$; the time of maintaining $\mathrm{T} \geq 60{ }^{\circ} \mathrm{C}$ was $2-4 \mathrm{~min}$., and $\mathrm{T} \geq 40{ }^{\circ} \mathrm{C} 12 \div 20 \mathrm{~min}$. In points $1 \mathrm{~T}$, $2 \mathrm{~T}$ temperature increased to 23,1 and 23,5 and deeper by about $2{ }^{\circ} \mathrm{C}$, however no strong impact of the recorded pikes was observed but rather cumulative actions, also of burning torches with which the staff moved along the plate and the increase of ambient temperature to $\mathrm{T}_{\text {out }}=25,4{ }^{\circ} \mathrm{C}$.

b. MA; the concrete slab was heated to $60 \div 80^{\circ} \mathrm{C}$ at the depth of. $0,5 \mathrm{~cm}$; temperature of $40^{\circ} \mathrm{C}$ was maintained for $220 \mathrm{~min}$; at a depth of about $5-10 \mathrm{~cm}$, the temperature increased to approx. $30{ }^{\circ} \mathrm{C}$, and in the lower and lower layers only a few degrees.

c. SMA, the concrete slab was heated to $40^{\circ} \mathrm{C}$ at the depth of. $0,5 \mathrm{~cm}$; maintained for $10 \mathrm{~min}$, and temperature higher than $30^{\circ} \mathrm{C}$ about 3 hours. At a depth of $10 \mathrm{~cm}$, the temperature increased to $20^{\circ} \mathrm{C}$. 
Table. 3 Temperature during placement of the waterproofing membrane on the slab (Oct. $\left.5^{\text {th }}\right)$. Local maxima of temperature are marked in bold; shadows indicate time, when $\mathrm{T} \geq 60^{\circ} \mathrm{C}$ or $\mathrm{T} \geq 40^{\circ} \mathrm{C}$.

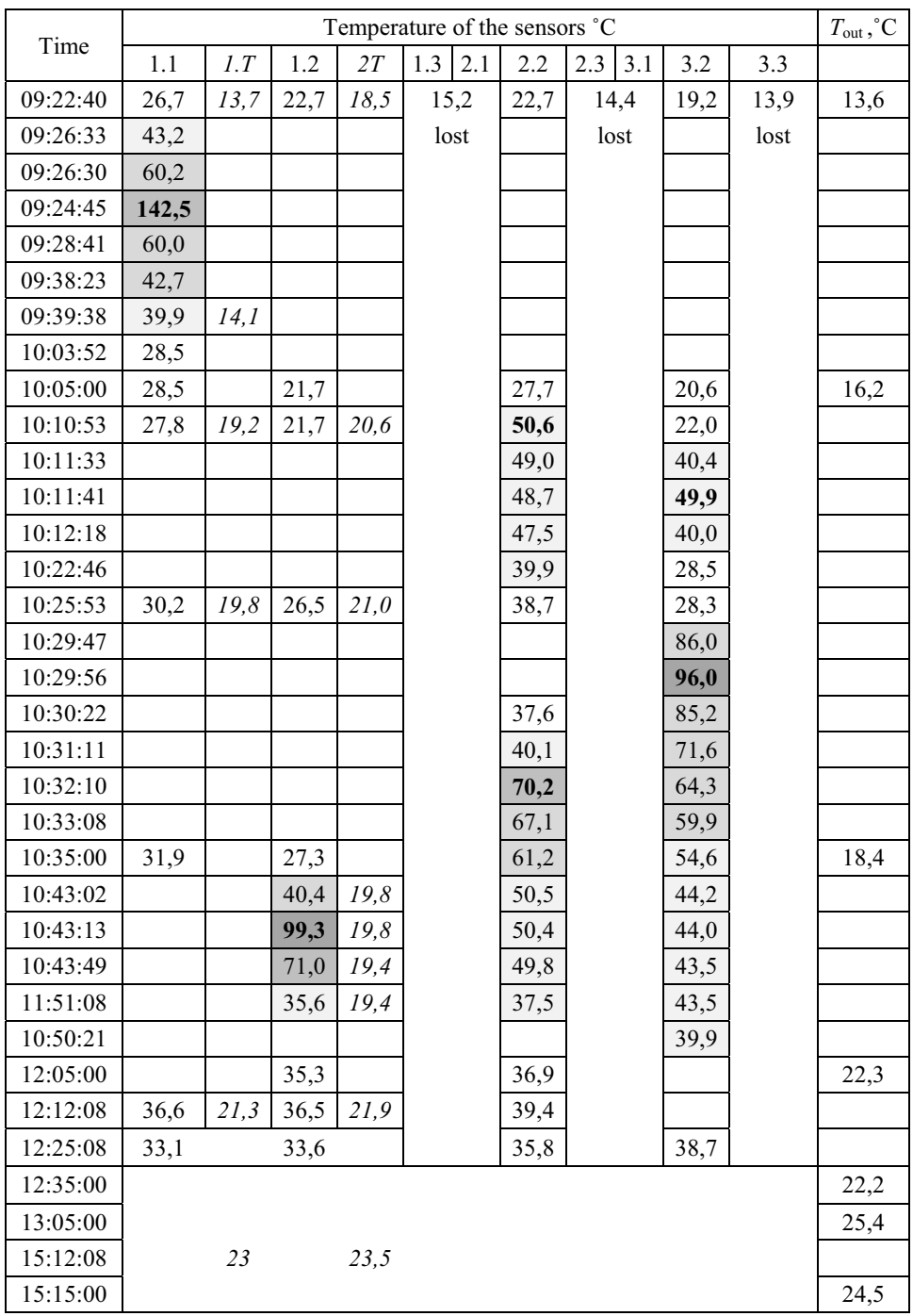




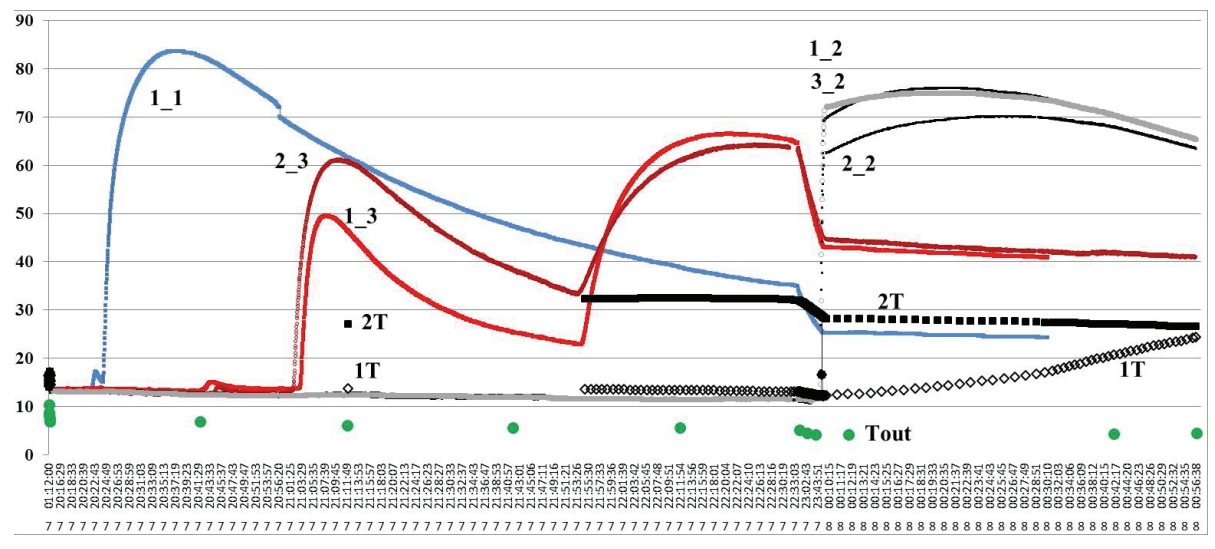

Fig. 10 Changes of the temperature on the slab surface under the waterproofing membrane during the mastic asphalt placement; the numbers indicate the sensors. The increase of temperature in the dipper parts of the slab is also seen; $1 \mathrm{~T}$ follows points no. 1_2,2_2,3_2 and 2T points no. 2_3,1_3). Tout - the ambient temperature; the number of data on the graph has been limited.

When the MA was placed (Tout $\leq 10{ }^{\circ} \mathrm{C}$ ) the sensors no. 1.1, 1_2, 3_2, 2_2 registered the maximum temperature of the slab surface between 83,4 and $70{ }^{\circ} \mathrm{C}$, which lasted from 40 to 220 min above $40^{\circ} \mathrm{C}$ (Fig.10). The sensor 1.3 (also 2_3) recorded two separate consecutive peaks i.e. $49,3{ }^{\circ} \mathrm{C}$, and then $66,4{ }^{\circ} \mathrm{C}$. It is because the MA was placed in two steps. In the same time the top part of the slab cross-section was heated from about $13-15{ }^{\circ} \mathrm{C}$ to $32.6{ }^{\circ} \mathrm{C}$ and the temperature higher than $30^{\circ} \mathrm{C}$ last for $2-3$ hours (outside the range of the Fig.10). 


\section{Conclusions}

1. It was found that concrete covered with bituminous insulation or MS and SMA is heated in the surface layer to a relatively high temperature, i.e. $60-140{ }^{\circ} \mathrm{C}$. The cooling rate is shorter for the membrane than the thicker, outer layers; in very favorable cold and windy conditions it lasted respectively up to 20 minutes and up to 4 hours.

2. The temperature also increase along the depth of the concrete deck cross section. The biggest impact is to the depth of about $10 \mathrm{~cm}$. The deck without waterproofing membrane reached the temperature $39,6{ }^{\circ} \mathrm{C}$ when the highest Tout $=41{ }^{\circ} \mathrm{C}$. During insulation placement the temperature raised from $14-14{ }^{\circ} \mathrm{C}$ to $23{ }^{\circ} \mathrm{C}$ and during MA placement from $13-15{ }^{\circ} \mathrm{C}$ to $32,6{ }^{\circ} \mathrm{C}$.

3. With high insolation and lack of wind, accumulation of thermal loads in the panel may occur and intensify the measured effects, i.e.:

- heating the concrete above $40^{\circ} \mathrm{C}$ in the cross section of the deck, at a depth up to $10 \mathrm{~cm}$, - increasing the energy absorption coefficient when the concrete is covered with black bituminous insulation; PN-EN provides for increasing the temperature of concrete under insulation by up to a factor of 1.5 ,

- heating the surface layer of concrete to $60-140{ }^{\circ} \mathrm{C}$ during placing the insulation and up to $60-80{ }^{\circ} \mathrm{C}$ while placing the asphalt pavement and suitable extending the cooling time.

4. Analysis of the thermal action on the materials during the construction of the bridge and the asphalt pavement indicates, that the existing conditions allow the reactions with gaseous products that can cause blistering. The temperature of concrete in the surface layer of the slab is high enough (40-60 C), that the rate of possible reactions between inorganic compounds in the concrete is significant. If the products of such reactions are gases, it can cause blistering. It is reasonable to assume that in summer, when the intensity of insolation is high and daily temperatures higher than during the study period (September/October), the effect of heat accumulation in the concrete slab will be stronger than demonstrated,

5. It was find out that bituminous materials are heated to very high temperature (500-800 C) during the process of melting and flowing down from the roll to the concrete surface. Than material reach temperature around but also above $300 \mathrm{C}$ for time when cooling down. Analysis of whether the temperature and time to which insulation is heated can lead to the pyrolysis of its components and the emission of gases in particular hydrogen is the subject of a separate work which will be published. 


\section{References}

1. Gajda T., Germaniuk K., Rymsza B.: Przegląd incydentów powstawania pęcherzy pod hydroizolacją na obiektach mostowych; Archiwum Instytutu Inżynierii Lądowej, Wydawnictwo Politechniki Poznańskiej nr 21/2016, ISSN 1897-4007, s. 113-124 (in Polish)

2. Chmielewska B.: "Destruction of waterproofing membrane on the viaduct deck due to blisters containing hydrogen", Archive of Civil Engineering, LIII, 4,2007, s.683-696

3. Czarnecki L., Chmielewska B., Czarnecki Z., Wolański M.: Zniszczenie izolacji bitumicznej na żelbetowej płycie estakady spowodowane wydzieleniem wodoru przez beton. Inżynieria i Budownictwo nr 10/2004

4. Koronne C.J., Buska J.S., Cortez E.R., Greatorex A.R.: Procedures for the evaluation of sheet membrane waterproofing. Special Report 99-11. US Army Corps of Engineering, 1999.

5. Fleming D.: Shedding Lights on Osmosis in Resin Flooring. Protective Coating Europe, 2 (9), 2004.

6. Laukkanen K., Paroll H., Pitkänen P., Vesikari E., Prevention of bridge deck sheet membrane waterproofing blistering. Finnish National Road Administration, Helsinki Final report 45/1998.

7. EN 13263-1:2009: Silica fume for concrete - Part 1. Definitions, requirements and conformity criteria

8. Buil M., Witier P., Paillere A.M.: Study of the production of hydrogen gas by the silica fume in cementitious materials, Laboratoire Central des Ponts et Chaussees, CANMET, September 1992

9. Edwards-Lajnef M., Aitcin P.C., Wenger F., Viers P., Galland J.: Test Method for the Potential Release of Hydrogen Gas from Silica Fume, Cement Concrete and Aggregate, 2 (19), 64-69, 1997

10. Fidjestøl P., Jørgensen O., Hydrogen Evaluation in Concrete Due to Free Silicon Metal in Microsilica, Cement, Concrete and Aggregate, 2 (19), 70-75, 1997

11. Zhang M-H., Malhotra V.M., Wolsiefer S.J.: Determination of free silicon content in silica fume and its effect on volume of gas released from mortars incorporating silica fume, ACI Materials Journal, 5 (97), 576-586, 2000

12. Ufnalski W.: Analiza termodynamiczna procesów wydzielania gazowego wodoru w wyniku reakcji krzemu z wodą lub wodorotlenkiem wapnia , [in Polish], study report, Warsaw University of Technology, 2004

13. Raport końcowy projektu Labiryntowa hydroizolacja obiektów inżynierskich. Kierownik projektu: Rymsza. B., Warszawa 2017.

14. Zobel H.: Naturalne zjawiska termiczne w mostach, WKŁ Warszawa 2003

15. PN-EN 1991-1-5 Eurokod 1. Oddziaływania na konstrukcje. Część 1-5: Oddziaływania ogólne Oddziaływania termiczne,

16. Budka E., Rabiega J., Woźnicki A.: Zjawisko pęcherzenia izolacji mostowych: przyczyny i sposoby przeciwdziałania, referat. XXII Seminarium „Współczesne metody budowy, wzmacniania i przebudowy mostów”, Rosnówko k. Poznania, 5-6 czerwca 2012 r.

17. Tramer A., Lipowiecka T., Kordas T., Wałega-Chwastek H., Wala T.: Analiza przyczyn powstawania pęcherzy gazowych na styku warstwy izolacyjnej z betonową płytą mostową

18. Radziszewski P., Piłat J., Sarnowski M., Król J., Kowalski J.K.: Nawierzchnie asfaltowe na obiektach mostowych, Oficyna Wydawnicza Politechniki Warszawskiej, Warszawa 2016 


\section{THERMAL ACTIONS ON THE MATERIALS DURING DECK AND PAVEMENT CONSTRUCTION}

Keywords: blistering, waterproofing membranes, bridge deck, asphalt pavements, thermal actions

\section{SUMMARY}

The work characterizes the blistering phenomenon of bituminous insulation and asphalt pavement on bridge structures. Two cases have been described in which large quantities of hydrogen have been detected in gases taken from the blisters. The known from publications mechanisms of blister formation on coatings have been quoted, which are used to explain the blistering of insulation and bridge pavements, usually without analysis of gas samples. The paper formulates the hypothesis of a "cold process" and "hot process" as potential blister formation mechanisms, in which hydrogen may be present. The article presents one of the stages of research on the verification of that hypotheses. The aim was to investigate thermal actions on materials during the construction of a bridge deck, during extreme temperature of the summer. Determination of the actual temperature to which mineral materials such as concrete and organic materials such as primer, bituminous insulation, mastic asphalt and SMA heat up during application is crucial in the investigation of possible mechanisms. The aim was also to investigate how the technological temperature of subsequent stacked layers affects those located below. Due to delays in some stages of the construction schedule, the placing of insulation and pavement was postponed to the period of cold seasons (September/October). This resulted in construction works being carried out at relatively low temperatures what together with wind cooled the object.

It was found out that during the bridge deck construction the concrete slab covered with bituminous waterproofing membrane or MA and SMA is heated in the surface layer to a relatively high temperature, i.e. $60-140{ }^{\circ} \mathrm{C}$. The temperature also increases along the depth of the deck cross section. The biggest impact is to the depth of about $10 \mathrm{~cm}$; the deck without waterproofing membrane reached the temperature of $39,6{ }^{\circ} \mathrm{C}$ when the highest ambient temperature in that time was $41{ }^{\circ} \mathrm{C}$, and during insulation placement the temperature raised from $14-15{ }^{\circ} \mathrm{C}$ to $23{ }^{\circ} \mathrm{C}$, during MA placement from $13-15{ }^{\circ} \mathrm{C}$ to $32,6{ }^{\circ} \mathrm{C}$. It is reasonable to assume that in summer, when the intensity of insolation is higher than during the study period the effect of heat accumulation in the concrete slab will be stronger. It was concluded, that the temperature of concrete of upper part of the deck is high enough $\left(\min .40-60{ }^{\circ} \mathrm{C}\right.$ ) to find, that the rate of potential reactions between inorganic compounds in the concrete is significant. If the products of such reactions are gases, it can cause blistering. It was also find out that bituminous materials are heated to very high temperature $\left(500-800{ }^{\circ} \mathrm{C}\right)$ during the process of melting and flowing down from the roll to the concrete surface. Than material reach temperature about but also above $300{ }^{\circ} \mathrm{C}$ for time when cooling down. Analysis of whether the temperature and time to which insulation is heated can lead to the pyrolysis of its components and the emission of gases in particular hydrogen is the subject of a separate work. 


\section{OBCIĄŻENIA TERMICZNE MATERIAŁÓW W TRAKCIE BUDOWY POMOSTU I NAWIERZCHNI DROGOWEJ}

Słowa kluczowe: pęcherzenie, izolacje przeciwwodne, mosty, nawierzchnie asfaltowe, obciążenia termiczne

\section{STRESZCZENIE}

W pracy scharakteryzowano zjawisko pęcherzenia izolacji bitumicznych i asfaltowych nawierzchni drogowych na obiektach mostowych. Opisano dwa przypadki, w których w gazach pobranych z pęcherzy wykryto duże ilości wodoru. Przytoczono znane z literatury mechanizmy powstawania pęcherzy na powłokach, które stosowane są do wyjaśniania pęcherzenia izolacji i nawierzchni mostowych często bez bez analizy gazów w pęcherzach. W pracy sformułowano hipotezę o „zimnym procesie” i „gorącym procesie” jako potencjalnym mechanizmie powstawania pęcherzy, w których składzie może występować wodór. Artykuł przedstawia jeden z etapów badań nad weryfikacją hipotez. Celem było zbadanie obciążeń cieplnych materiałów w trakcie budowy obiektu mostowego, podczas ekstremalnej temperatury w okresie letnim. Określenie rzeczywistej temperatury do jakiej nagrzewają się w trakcie aplikacji materiały mineralne jak beton i materiały organiczne jak środek gruntujący, izolacja bitumiczna, asfalt lany i mieszanka mineralno asfaltowa jest kluczowe w dyskusji możliwych mechanizmów. Celem było także zbadanie jak temperatura technologiczna kolejnych układanych warstw wpływa na te położone poniżej. Z powodu opóźnień w niektórych etapach harmonogramu budowy układanie izolacji i nawierzchni przesunięto na okres chłodów września i października. Spowodowało to, że roboty budowlane odbywały się przy względnie niskich temperaturach, które szczególnie w nocy i z udziałem wiatru wychładzały obiekt.

Badania wykazały, że w trakcie budowy pomostu płyta betonowa pokryta bitumiczną izolacją przeciwwodną lub MA i SMA jest ogrzewana w warstwie powierzchniowej do względnie wysokiej temperatury tj. 20-140 ${ }^{\circ} \mathrm{C}$. Temperatura rośnie także na głębokości przekroju płyty pomostu. Największe oddziaływanie występuje do głębokości ok. $10 \mathrm{~cm}$; pomost bez izolacji przeciwwodnej osiągnął temperaturę $39,6{ }^{\circ} \mathrm{C}$ gdy najwyższa temperatura otoczenia w tym czasie wynosiła $41^{\circ} \mathrm{C}$, a w trakcie układania izolacji temperatura wzrosła z 14 $15{ }^{\circ} \mathrm{C}$ to $23{ }^{\circ} \mathrm{C}$, podczas układania MA z $13-15{ }^{\circ} \mathrm{C}$ to $32,6{ }^{\circ} \mathrm{C}$. Wydaje się uzasadnione założenie, że w lecie, gdy intensywność nasłonecznienia jest wyższa niż w okresie prowadzenia badań efekt kumulacji ciepła w płycie betonowej będzie silniejszy. Stwierdzono, że temperatura betonu w górnej części płyty pomostu jest wystarczająco wysoka (min. $40-60{ }^{\circ} \mathrm{C}$ ) żeby uznać, że szybkość potencjalnych reakcji między mineralnymi składnikami betonu jest istotna. Jeśli produktami takich reakcji są gazy, mogą spowodować wystąpieine pęcherzy. Stwierdzono także, że materiały bitumiczne są ogrzewane do bardzo wysokiej temperatury (500$800{ }^{\circ} \mathrm{C}$ ) podczas roztapiania i spływania z rolki na powierzchnię beton. Następnie materiały uzyskują temperaturę około ale i powyżej $300 \mathrm{C}$ gdy stygną. Analiza czy temperatura i czas jej oddziaływania może prowadzić do pirolizy składników i emisji gazów, w szczególności wodoru jest przedmiotem odrębnej pracy 